\section{Penilaian Cepat Bangunan Sekolah Pasca Gempa Bumi Palu}

\author{
As'at Pujianto, Restu Faizah, \\ Fanny Monika, Hakas Prayuda
}

Program Studi Teknik Sipil, Fakultas Teknik, Universitas Muhammadiyah Yogyakarta, Jl. Brawijaya, Kasihan, Bantul, Yogyakarta, 55183.

pujiantoasat@umy.ac.id

\begin{abstract}
Pada tanggal 28 September 2018, terjadi gempa bumi dengan kekuatan 7,4 SR pada kedalaman $10 \mathrm{~km}$. Pusat gempa berada di $26 \mathrm{~km}$ utara Donggala dan $80 \mathrm{~km}$ barat laut kota Palu. Terjadinya gempa ini dipicu oleh aktivitas laut Koro Palu dengan mekanisme patahan. Ribuan bangunan dilaporkan mengalami kerusakan mulai dari kerusakan ringan hingga kerusakan parah, termasuk bangunan-bangunan sekolahan milik Muhammadiyah. Kajian ini bertujuan untuk melakukan penilaian terhadap bangunan sekolah yang didirikan oleh Muhammadiyah. Dalam kajian ini, penilaian tingkat kerusakan bangunan menggunakan metode yang dirilis oleh World Seismic Safety Initiative pada 2007. Penilaian dilakukan di 37 gedung sekolah yang terdiri dari 1 lantai hingga 2 lantai. Hasil analisis menunjukkan bahwa $90 \%$ bangunan dibangun tanpa analisis struktural yang benar dan tidak dirancang untuk tahan gempa. Selain itu, beberapa bangunan dikategorikan cukup tua dan tidak dilakukan perawatan secara intensif. Hasil kajian menunjukkan bahwa hanya satu bangunan yang termasuk dalam kategori rusak berat karena rusaknya fondasi. Sementara itu, bangunan lain mengalami kerusakan pada komponen non strukturalnya yang dikategorikan rusak sedang dan rusak ringan.

Kata kunci : pasca gempa, penilaian gedung, Palu, analisis struktural

Diajukan: 13 September 2019

Direvisi: 14 September 2019

Diterima: 2 Oktober 2019

Dipublikasikan online:3 Oktober 2019
\end{abstract}

\section{Pendahuluan}

Gempa tektonik berkekuatan 7,4 SR yang terjadi di Palu Provinsi Sulawesi Tengah pada hari Jumat, 28 September 2018. Menurut Badan Meteorologi Klimatologi dan Geofisika Indonesia, dampak gempa bumi dengan kedalaman $10 \mathrm{~km}$ terasa hingga beberapa provinsi di sekitarnya seperti di Sulawesi Selatan, Gorontalo, Kalimantan Timur, hingga Kalimantan Utara. Gempa bumi di Donggala dipicu oleh aktivitas patahan Palu Koro dengan mekanisme strike-slip diikuti oleh Tsunami dan Likuefaksi yang terjadi di beberapa titik. Tsunami terjadi di daerah pantai Talise, sedangkan likuefaksi terjadi di Balaroa, Jono Oge, Petobo, dan Sigi.

Gempa bumi, tsunami, dan likuefaksi menyebabkan ribuan orang meninggal dan hilang, dan ribuan rumah rusak. Beberapa laporan juga menyatakan bahwa kerusakan juga terjadi di fasilitas umum seperti bangunan keagamaan, sekolah, hotel, rumah sakit dan beberapa infrastruktur seperti jalan dan jembatan. Berdasarkan pengamatan Badan Meteorologi Klimatologi dan Geofisika (BMKG), gempa susulan berlanjut hingga dua minggu ke depan dengan magnitudo terbesar sebesar 6,3 $\mathrm{M}$ dan magnitudo terkecil dari sebesar 2,9 M. Berdasarkan data Kementerian Pendidikan dan Kebudayaan Republik Indonesia, ada 2.736 gedung sekolah rusak. Bangunan-bangunan itu, antara lain, adalah 37 gedung sekolah milik Amal Usaha Muhammadiyah (AUM) yang terdiri dari Taman Kanak-kanak, Sekolah Dasar,
Sekolah Menengah Pertama, dan Sekolah Menengah Atas. Bangunan sekolah ini tersebar di beberapa kota seperti Sigi, Donggala, dan Palu.

Berdasarkan pengamatan relawan dari Pusat Manajemen Bencana Muhammadiyah (MDMC), hingga dua bulan setelah gempa, sebagian besar siswa belajar di tendatenda di halaman sekolah. Hal tersebut karena ada perasaan traumatis untuk memasuki ruang kelas yang rusak. Sebagian besar orang yang menggunakan gedung sekolah ini merasa tidak yakin dengan kemampuan struktur bangunan dalam menahan beban, terutama ketika terjadi gempa susulan yang cukup besar. Masalah ini merupakan salah satu kendala dalam proses pemulihan pendidikan yang bertujuan untuk menormalkan kondisi proses pendidikan seperti sebelum gempa bumi atau bahkan dengan prestasi yang lebih baik. Oleh karena itu, perlu dilakukan penyelidikan atau penilaian terhadap kondisi bangunan yang rusak, sehingga proses rehabilitasi dan rekonstruksi dapat segera dilakukan.

Pengabdian ini menggunakan panduan cara cepat dalam memeriksa keamanan bangunan tembokan sederhana yang rusak akibat gempa (Boen, 2017). Melalui metode ini, penilaian dilakukan dengan cara langsung mengamati kondisi fisik baik struktural maupun nonstruktural. Dari hasil ini, bangunan diklasifikasikan tingkat kerusakannya. Penilaian tingkat kerusakan bangunan setelah gempa sangat diperlukan. Beberapa penelitian sebelumnya di berbagai negara melakukan hal yang sama,

Cara mensitasi artikel ini:

Pujianto, A., Faizah, R., Monika, F., Prayuda, H (2019) Penilaian Cepat Bangunan Sekolah Pasca Gempa Bumi Palu. Buletin Profesi Insinyur 2(2) 081-085 
seperti India (Sarmah dan Das, 2018; Jain, dkk, 2010; Rajarathnam dan Santhakumar, 2015), Indonesia (Idham, 2011; Prayuda, dkk, 2017), Italia (Faccioli, dkk, 1999; D'Ayala dan Paganoni, 2011), Austria (Achs dan Adam, 2012) dan Turki (Ozhemdekci dan Ozhendekci, 2012). Metode yang digunakan dalam penilaian bangunan sangat bervariasi sesuai dengan perkembangan ilmu pengetahuan. Beberapa metode yang telah dilakukan adalah Logic Fuzzy (Allali, dkk, 2018; Sen, 2010; Demartinos dan Dritsos, 2006), Analisis Statistik (Ningthoujam dan Nanda, 2018) dan berdasarkan Standar FEMA (Perrone, dkk, 2015; El-Betar, 2018).

\section{Metode}

Metode pelaksanaan ini menggunakan metode survei langsung ke lapangan dan mencatat data-data penting tentang kondisi bangunan. Beberapa tahapan yang dilakukan dalam mengevaluasi bangunan pasca gempa bumi sebagai berikut :

a. Semua peralatan disiapkan terlebih dahulu, seperti : kamera, lembar formulir dan GPS untuk proses pengumpulan data dan menentukan lokasi bangunan.

b. Buat peta lokasi dan peta struktur bangunan untuk setiap lantai. Proses pengisian formulir dilakukan untuk setiap lantai dan kemudian hasilnya dirata-rata.

c. Komponen yang dinilai terdiri dari tiga bagian yaitu, komponen pondasi, komponen vertikal, dan komponen horisontal. Komponen pondasi terdiri dari pondasi batu kali, balok pondasi, dan pondasi telapak beton. Komponen vertikal terdiri dari kolom, sambungan balok kolom, dinding retak diagonal, dinding retak pada sambungan balok atau kolom, dinding runtuh dan dinding partisi. Sedangkan pada komponen horizontal, evaluasi hanya dilakukan pada balok, pelat dan rangka atap.

d. Dalam mengisi formulir evaluasi, tingkat kerusakan dipisahkan menjadi empat bagian, yaitu tidak ada kerusakan, kerusakan ringan, kerusakan sedang, dan kerusakan berat. Cara untuk menentukan tingkat kerusakan telah ditentukan dalam standar sesuai dengan lebar retakan yang terbentuk setelah gempa.

e. Setelah evaluasi, bangunan ditandai apakah layak digunakan atau harus diperbaiki terlebih dahulu atau komponen yang tidak layak harus diganti dengan komponen baru.

\section{Hasil Kerja}

\section{Pengamatan Cara Cepat}

Pengamatan cara cepat merupakan salah satu cara untuk mengevaluasi fisik bangunan secara cepat dengan mengisi formulir yang disiapkan sebelumnya. Formulir berisi data primer dari gedung yang dinilai. Penilaian kerentanan bangunan menggunakan lembar RVS telah dikelola secara umum sesuai dengan standar (FEMA, 2000). Secara umum, beberapa hal yang penting untuk dicatat untuk menganalisis kerentanan bangunan menurut FEMA 154 antara lain, adalah seismisitas lokasi, di mana nilai percepatan spektral diperlukan, dan data fungsi bangunan serta jumlah populasi. Hal-hal yang perlu dinilai adalah jenis tanah, unsur nonstruktural yang berbahaya, jenis bangunan, jumlah lantai, ketidakteraturan vertikal, dan ketidakteraturan rencana dan tahun bangunan itu dibangun.
Dalam pengamatan ini, evaluasi dilakukan terutama untuk bangunan sederhana satu atau dua lantai yang terkena dampak gempa bumi mengacu pada standar yang dibuat oleh World Seismic Safety Initiative (Boen, 2017).

Tingkat kerusakan pada setiap komponen terdiri dari :

a. Tidak ada kerusakan yang berarti.

b. Kerusakan ringan, kerusakan struktur hanya memerlukan perbaikan penutup plesteran dan komponen non-struktur yang perlu dipulihkan.

c. Kerusakan sedang, kerusakan struktur yang masih bisa/dapat diperbaiki.

d. Kerusakan parah, kerusakan demikian luasnya, sehingga jika ingin diperbaiki, banyak yang harus dibongkar dan diganti.

Evaluasi yang dilakukan terhadap bangunan tembokan sederhana dilakukan pada : komponen vertikal yang berupa kolom dan dinding, komponen horizontal yang berupa balok dan pelat serta pondasi. Tingkat kerusakan setiap komponen dimulai dari 0 hingga 100, di mana semakin tinggi jumlah tingkat semakin aman bangunan. Beberapa hal penting ketika melakukan evaluasi adalah (Boen, 2017) :

a. Retak rambut pada beton (kurang dari $0,2 \mathrm{~mm}$ ) atau retak tidak terlihat menunjukkan kerusakan yang tidak berarti.

b. Umumnya, retak pada komponen beton hingga lebar 2 $\mathrm{mm}$ tidak dianggap sebagai sesuatu yang berbahaya, dan dapat dikategorikan sebagai kerusakan ringan.

c. Retak pada komponen beton hingga $5 \mathrm{~mm}$ mengindikasikan kerusakan sedang.

d. Retak pada komponen beton lebih dari $5 \mathrm{~mm}$ menunjukkan kerusakan berat, sehingga mengakibatkan berkurangnya kekuatan.

e. Tertekuknya tulangan pada komponen beton, mengindikasikan adanya kerusakan yang berat, dengan tidak memperhatikan lebar retak beton.

f. Retak-retak atau robohnya partisi tidak menyatakan kerusakan struktur yang berarti.

\section{Tingkat Keamanan Komponen Vertical}

Evaluasi atau penilaian dilakukan secara bertahap di setiap lantai. Gambar 1 menunjukkan beberapa kerusakan akibat gempa. Kebanyakan kerusakan terjadi pada dinding, terutama dinding yang memiliki pintu atau jendela. Itu karena kurangnya ikatan atau koneksi antara dinding. Gambar 1 menunjukkan bahwa dinding memiliki celah diagonal yang mengarah ke dinding yang tidak memiliki ikatan, sehingga melemahkan bagian dinding ini.

Gambar 2 menunjukkan tingkat keamanan setiap bangunan yang dinilai dari komponen vertikal. Dalam komponen ini, ada beberapa bangunan yang rusak berat, bangunan rusak ringan dan tidak ada yang rusak. Berdasarkan gambar 2 tersebut menunjukan 62\% bangunan tidak mengalami kerusakan atau hampir tidak ada kerusakan sama sekali, 30\% bangunan mengalami rusak ringan, 5\% menderita kerusakan sedang, dan 3\% mengalami kerusakan cukup berat.

Penilaian komponen vertikal ini difokuskan pada kolom, dinding, sambungan balok-kolom, hingga hubungan antara dinding dan balok atau kolom. Sebagian besar kondisi kerusakan ringan terjadi pada dinding dengan kondisi retak kurang dari $5 \mathrm{~mm}$. Selain itu, kondisi beberapa bangunan 
yang cukup tua dan kurang perawatan adalah penyebab retakan yang lebih besar.

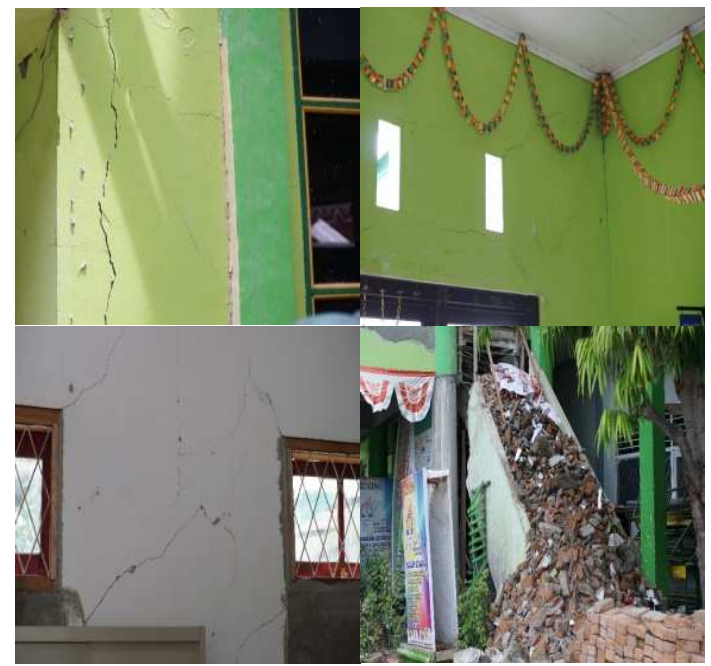

Gambar 1. Kerusakan yang disebabkan oleh gempa bumi

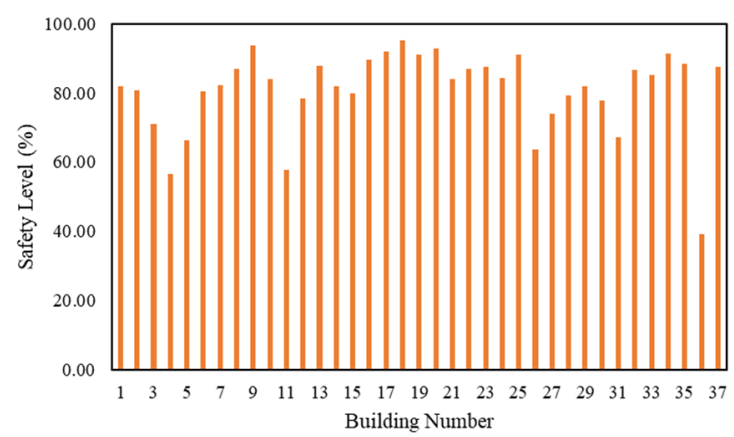

Gambar 2. Tingkat keamanan komponen vertical

\section{Tingkat Keamanan Komponen Horisontal}

Penilaian komponen horisontal dapat dilihat pada Gambar 3 yang menunjukkan tingkat kerusakan yang tidak jauh berbeda dari penilaian komponen vertikal. Penilaian komponen horisontal ini difokuskan pada kondisi balok, struktur atap, dan pelat. Gambar 3 menunjukkan bahwa $73 \%$ bangunan mengalami sedikit kerusakan atau hampir tidak ada kerusakan sama sekali, $19 \%$ mengalami kerusakan ringan, 5\% mengalami kerusakan sedang, dan $3 \%$ mengalami kerusakan berat. Sebagian besar kerusakan terjadi di atap. Banyak bangunan sekolah menggunakan struktur atap yang cukup tua, dan sambungan langitlangitnya tidak cukup baik sehingga beberapa langit-langit runtuh. Sementara itu, dalam penilaian pondasi (Gambar 4), 97\% bangunan tidak mengalami kerusakan pada fondasinya, dan 3\% mengalami kerusakan yang cukup berat. Dapat dilihat secara visual bahwa tanah di dalam bangunan telah berubah, sehingga dikhawatirkan dapat merusakan kondisi bangunan. Ada banyak kendala dalam proses penilaian fondasi ini, karena sangat sulit untuk melakukan penilaian visual dengan benar. Jadi penilaian hanya dilakukan berdasarkan kondisi tanah dan beberapa perubahan yang sangat jelas dari bangunan di sekitar fondasi.

\section{Tingkat Keamanan Gedung Sekolah}

Gambar 5 menunjukan penilaian keseluruhan bangunan, sedangkan Gambar 6 (b) adalah hasil akhir dari kondisi bangunan yang telah dinilai.

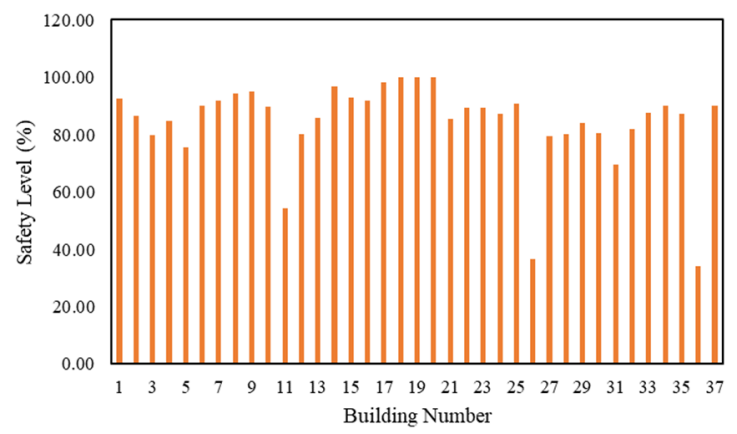

Gambar 3. Tingkat keamanan komponen horizontal

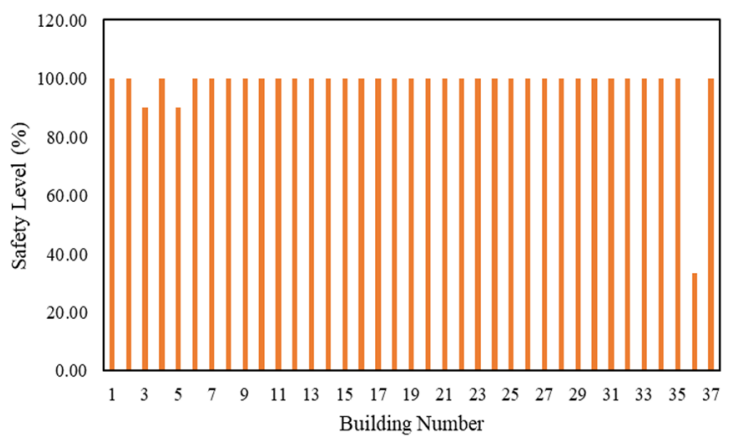

Gambar 4. Tingkat keamanan komponen fondasi

Gambar menunjukkan bahwa $81 \%$ bangunan mengalami sedikit kerusakan atau hanya perlu membersihkan sisa-sisa material. Sementara itu, $13 \%$ bangunan mengalami sedikit kerusakan dengan kondisi dinding retak cenderung kurang dari $2 \mathrm{~mm}$ dan tidak mengalami kerusakan berat pada komponen strukturnya. Kerusakan sedang adalah 3\%, dan kerusakan berat adalah $3 \%$, bangunan-bangunan itu perlu diperbaiki dan tidak aman untuk digunakan sebelum mengganti beberapa komponen dan melakukan analisis struktur yang benar.

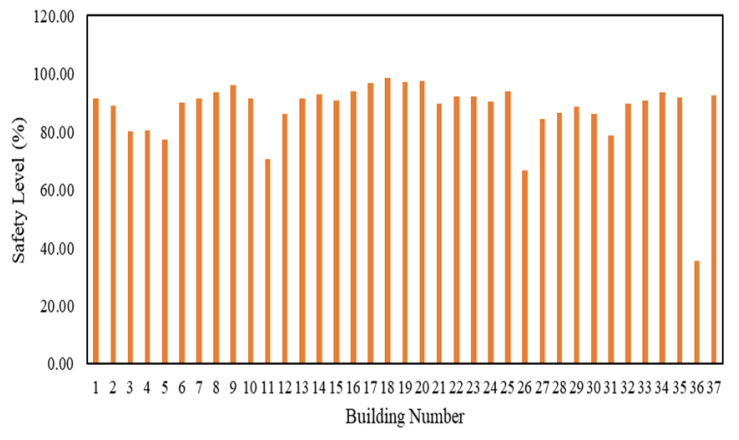

Gambar 5. Tingkat keamanan gedung sekolah

Gambar 6 (a) menunjukkan bahwa 52\% dari kerusakan adalah komponen vertikal, sementara $42 \%$ dari itu adalah 
komponen horizontal. Ini menunjukkan bahwa kedua komponen ini secara signifikan mempengaruhi tingkat kerusakan bangunan jika penilaian dilakukan secara visual. Sementara itu, komponen fondasi hanya 6\%. Setelah penilaian selesai, setiap bangunan diberi tanda layak atau tidak layak untuk ditempel. Dengan demikian, agar masyarakat sekolah dapat memanfaatkan area secara efisien. Satu gedung sekolah dari 37 mengalami kerusakan parah dari semua komponen, sehingga bangunan ini direkomendasikan untuk dibangun kembali.

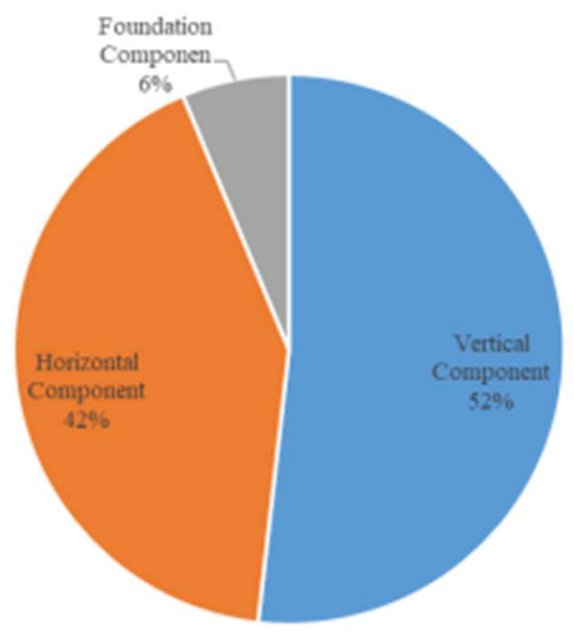

(a)

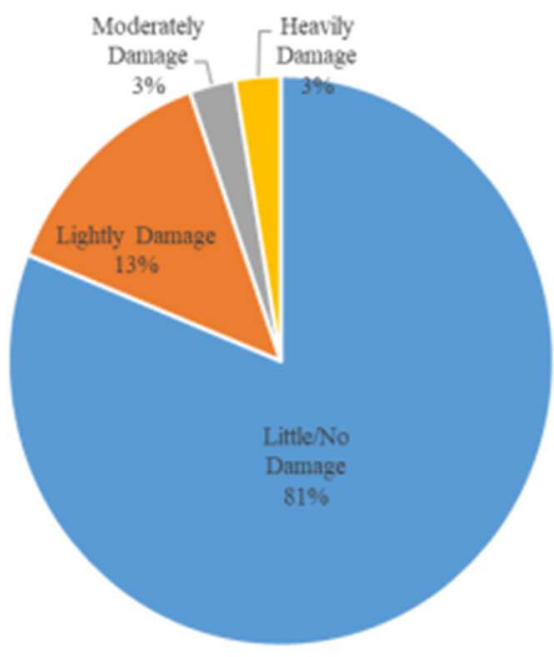

(b)

Gambar 6. (a) Persentase komponen yang rusak (b) Persentase kerusakan

\section{Persentase Komponen Bangunan Yang Rusak}

Gambar 7 menunjukkan persentase komponen bangunan yang rusak. Studi ini menemukan bahwa hubungan antara dinding dan kolom atau balok adalah kerusakan paling besar yaitu sebesar $20 \%$, sedangkan dinding yang retak secara diagonal sebesar $18 \%$. Kerusakan yang terjadi pada struktur seperti pelat, balok, kolom, dan sambungan pada balok dan kolom masing-masing berkisar 10-11 \%. Sementara itu, kerusakan pada struktur atap sebesar $15 \%$ dan pada fondasi dan sloof kerusakan berkisar antara 1-2 \%. Dengan demikian, dapat disimpulkan bahwa dinding merupakan komponen yang paling rusak, sehingga perlu dipertimbangkan prosedur dan perkuatan bangunan yang harus dilakukan selama proses konstruksi.

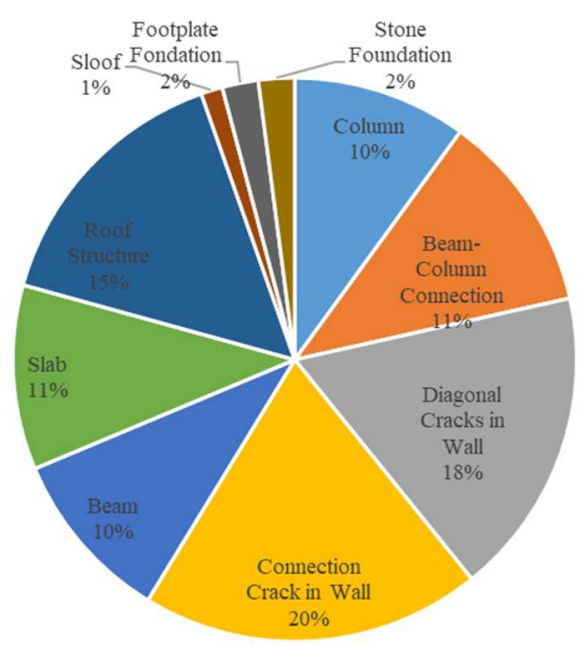

\section{Gambar 7. Persentase komponen bangunan yang} rusak

\section{Kesimpulan}

Berdasarkan hasil dan pembahasan, dapat disimpulkan sebagai berikut :

a. Bangunan dapat dinyatakan tidak rusak secara struktural sebesar $81 \%$, bangunan rusak sebesar $13 \%$ pada komponen non-strukturnya, dan bangunan rusak sebesar $6 \%$ pada komponen strukturalnya, sehingga perlu ditinjau secara rinci tentang kekuatannya.

b. $52 \%$ kerusakan berasal dari komponen vertikal, $42 \%$ kerusakan berasal dari komponen horizontal, dan $6 \%$ kerusakan berasal dari komponen pondasi.

c. Komponen Fondasi sangat sulit untuk dinilai secara visual. Tinjauan tentang keamanan gedung secara ditail perlu dilakunan penelitian lebih dalam.

d. Dinding adalah area yang paling rusak, $20 \%$ kerusakan terjadi pada sambungan dinding dengan balok atau kolom, dan $18 \%$ dinding memiliki retakan diagonal.

\section{Ucapan Terimakasih}

Penulis mengucapkan ucapan terima kasih kepada LP3M Universitas Muhammadiyah Yogyakarta, dan kepada Pusat Studi Lingkungan dan Bencana (PSLB) yang telah membantu dalam melaksankan pengabdian ini serta kepada Muhammadiyah Disaster Management Center (MDMC) yang memfasilitasi proses pengabdian, serta semua sekolah yang telah membantu dan menyediakan waktu ketika dilakukan assesment.

\section{Referensi}

Achs. G., and C. Adam (2012) Rapid Seismic Evaluation of Historic Brick-Masonry Buildings in Vienna (Austria) Based on Visual Screening. Bulletin Earthquake Engineering. 10. 1833-1856. 
Allali. S. A., M. Abed., and A. Mebarki (2018) PostEarthquake Assessment of Buildings Damage Using Fuzzy Logic. Engineering Structures. 166. Pp. 117127.

Boen, T. (2017) Kajian Cara Cepat Keamanan Bangunan Tembokan Sederhana Satu atau Dua Lantai yang Rusak akibat Gempa dan Kajian Risiko Komponen Non-Struktural. World Seismic Safety Initiative.

D'Ayala. D. F, dan S. Paganoni (2011) Assessment and Analysis of Damage in L'Aquila Historic City Centre after $6^{\text {th }}$ April 2009. Bulletin Earthquake Engineering. 9. Pp. 81-104.

Demartinos., Z dan S. Dritsos (2006) First Level PreEarthquake Assessment of Buildings Using Fuzzy Logic. Earthquake Spectra. 22. Pp. 865-885.

El-Betar., S. A. (2018) Seismic Vulnerability Evaluation of Existing R.C. Buildings. Housing and Building National Research Center Journal. 14. Pp. 189-197.

Faccioli. E., V. Pessina., G. M. Calvi., dan B. Borzi. (1999) A Study on Damage Scenarios for Residential Buildings in Catania City. Journal of Seismology. 3. Pp. 327-343.

FEMA (2000) FEMA 154: Rapid Visual Screening of Building for Potential Seismic Hazards: A Handbook. Federal Emergency Management Agency. USA

Idham, N.C. (2011) Seismic Vulnerability Assessment in Vernacular Houses: The Rapid Visual Screening Procedure for Non Engineered Building with Application to Java Indonesia. PhD Thesis. Eastern Mediterranean University.

Jain. S.K, M. Eeri., K. Mitra., M. Kumar., dan M. Shah. (2010) A Proposed Rapid Visual Screening Proceduse for Seismic Evaluation of RC-Frame Buildings in India. Earthquake Spectra. 26. Pp. 709-729.
Ningthoujam., M. C., dan R. P. Nanda (2018) Rapid Visual Screening Procedure of Existing Building Based on Statistical Analysis. International Journal of Disaster Risk Reduction. 28. Pp. 720-730.

Ozhemdekci., N, dan D. Ozhendekci (2012) Rapid Seismic Vulnerability Assessment of Low to Mid-Rise Reinforced Concrete Buildings Using Bingol's Regional Data. Earthquake Spectra. 28. Pp. 11651187.

Perrone., D., M. A. Aiello., M. Pecce., and F. Rossi. (2015) Rapid Visual Screening for Seismic Evaluation of RC Hospital Buildings. Structures. 3. Pp. 57-70.

Rajarathnam, S dan A. R. Santhakumar (2015) Assessment of Seismic Building Vulnerability Based on Rapid Visual Screening Technique Aided by Aerial Photographs on a GIS Platform. National Hazards. 78. Pp.779-802.

Prayuda, H., A. Pujianto., P. Astuti., R. Faizah., and J. Ikhsan (2017) Evaluasion of Al-Iman Mosque Building Structure in Pidie Jaya Regency Special District of Aceh Using Rapid Visual Screening After Earthquake December 7 2016. Prociding Pertemuan IImiah $4^{\text {th }}$ Riset Kebencanaan. Ikatan Ahli Bencana Indonesia. Pp. 249-261.

Sarmah. T, dan S. Das. (2018) Earthquake Vulnerability Assessment for RCC Buildings of Guwahati City using Rapid Visual Screening. $7^{\text {th }}$ International Conference on Building Resilience: Using Scientific Knowledge to Inform Policy and Practice in Disaster Resk Reduction. 121. Pp. 214-221.

Sen., Z, (2010) Rapid Visual Earthquake Hazard Evaluation ef Existing Buildings by Fuzzy Logic Modelling. Expert Systems with Applications. 37. Pp. 5653-5660. 